\section{Jiř́i Lom is 75}

It is an extreme pleasure for me to have been granted an exception from the editorial rules of Folia, which normally does not publish anniversary notes. But Dr. Jiří Lom, who accomplished 75 years of his fruitful life on 24 October 2006, has been a very special person for Folia. His anniversary certainly should not pass unnoticed, especially in this journal whose success has been largely dependent on his commitment. As one who also was "in" when Dr. Lom took over as Editor-in-Chief of Folia in 1991, and also one who is fortunate to work in the field of fish parasitology, I shall attempt a brief outline of Dr. Lom's great achievements as the internationally most recognised Czech fish parasitologist and an excellent editor.

It is impossible to record here even Dr. Lom's most significant contributions to the field of protozoology and fish parasitology. His broad interests include morphology, ultrastructure, taxonomy, life-cycles and pathogenicity of diverse groups of protists infecting fishes, especially ciliates (trichodinids and peritrichs), myxosporeans, microsporidians and blood flagellates. His impact on science in these areas has been tremendous, as shown in a short list of key publications overleaf. For his excellence in research, among other honours, he gained a high recognition in 1996, being elected member of the Learned Society of the Czech Republic, the elite body of eminent Czech scientists.

Dr. Lom's outstanding career has been connected almost exclusively with the Czechoslovak Academy of Sciences (since 1993, Academy of Sciences of the Czech Republic), where at the Institute of Parasitology he was Scientific Secretary and head of the Department of Protozoology for decades and Director of the Institute from 1990 to 1994. During his directorship, Dr. Lom coped with extremely difficult administrative duties, as the reduced budget and pressure from the government towards slimming down of the Academy of Sciences required making major changes in the structure of the Institute, including a considerable reduction in the staff. He did this with deep insight into the needs of modern science, effectiveness and great consideration, and should be remembered as the key person responsible for the transformation and modernisation of the Institute of Parasitology.

Despite onerous administrative duties in the early 1990s and partial retirement in 1996, Dr. Lom has continued his research. He still is one of the key scientists of the Institute, with the highest citation rate among all colleagues, between 100 and 200 citations yearly and Hirsch index 32 (ISI Web of Science $\left.{ }^{(}\right)$database), another testimony of an impressive and enduring impact on the areas of his continuing work.

Due to his highly recognized work, early in his career, Dr. Lom became conversant with the editorial policy of leading journals where he published and served on Editorial Boards. This was invaluable especially while Folia was transformed from a periodical of local impact into a truly international journal in the 1990s. Also, his friendship and

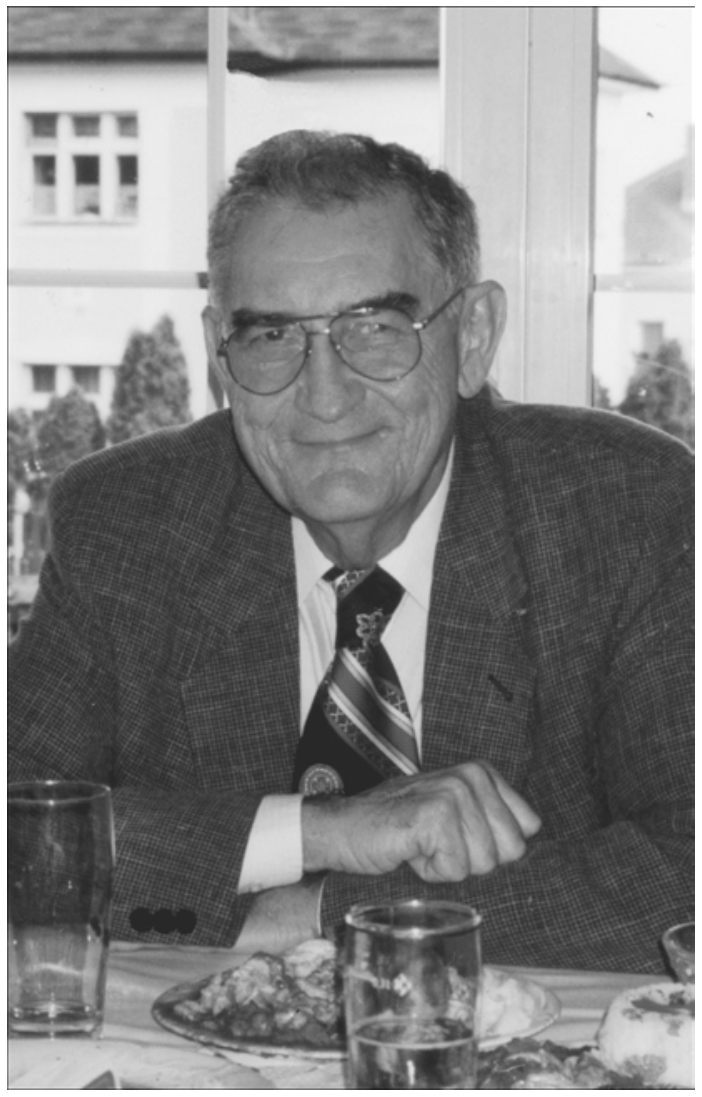

collaborations with leading researchers in the USA, Canada and France, as well as an excellent command of English, German, French and Russian, have been a great asset.

I had the privilege of serving as Acting Editor of Folia under the guidance of Dr. Lom for almost 8 years in the 1990s. It was a difficult time when we struggled for a reasonable standard, accepting only quality papers after a demanding peer review. This made Folia unattractive for many of the previous contributors. In the beginning the "new" Folia offered only a modest value (impact) to authors of quality papers, resulting in a low influx of manuscripts. Fortunately, these years are history and Folia has firmly established a good position among parasitological journals. I am sure this would never have happened without Dr. Lom's dedicated service as Editor-in-Chief for 11 years, Assistant Editor since 2002, and contributor of highly cited papers over many years.

Finally, as the Director of the Institute of Parasitology, I would like to express my personal gratitude to Dr. Lom for all his work for the Institute and Folia Parasitologica. I wish him good health, vigour and many happy days. May he continue to write important papers and share his extraordinary knowledge with younger parasitologists for many years to come.

Tomáš Scholz 


\section{Selected key publications by Jiří Lom}

\section{Monographs}

Canning E.U., Lom J. (with contribution of I. Dyková) 1986 The Microsporidia of Vertebrates. Academic Press, London, 289 pp. [355]*

Lom J., Dyková I. 1992: Protozoan Parasites of Fishes. Developments in Aquaculture and Fisheries Science, Vol. 26. Elsevier, Amsterdam, 315 pp. [440]

\section{Chapters in monographs}

Lom J. 1979: Biology of the trypanosomes and trypanoplasms of fish. In: W.H.R. Lumsden and D.A. Evans (Eds.), Biology of the Kinetoplastida, Vol. 2. Academic Press, New York, pp. 269-337. [94]

Lom J. 1985: Diseases caused by protistans. In: O. Kinne (Ed.), Diseases of Marine Animals, Vol. IV, Part. 1. Biologische Anstalt Helgoland, Hamburg, pp. 114-168. [29]

Lom J. 1990: Phylum Myxozoa. In: L. Margulis, J.O. Corliss, M. Melkonian and D.J. Chapman (Eds.), Handbook of Protoctista. Jones and Bartlett Publishers, Boston, pp. 3652. [45]

Lom J. 1995: Trichodinidae and other ciliates (Phylum Ciliophora). In: P.T.K. Woo (Ed.), Fish Diseases and Disorders, Vol. 1, Protozoan and Metazoan Infections. CAB International, Wallingford, pp. 229-262. [17]

Lom J., Dyková I. 1995: Myxosporea (Phylum Myxozoa). In: P.T.K. Woo (Ed.), Fish Diseases and Disorders, Vol. 1, Protozoan and Metazoan Infections. CAB International, Wallingford, pp. 97-148. [35]

\section{Articles}

Lom J. 1958: A contribution to the systematics and morphology of endoparasitic trichodinids from amphibians with a proposal of uniform specific characteristics. J. Protozool. 5: 251-263. [83]

Lom J., Vávra J. 1963: The mode of sporoplasm extrusion in microsporidian spores. Acta Protozool. 1: 81-90, Pl. 2. [73]

Lom J. 1964: The morphology and morphogenesis of the buccal ciliary organelles in some peritrichous ciliates. Arch. Protistenkd. 107: 131-162. [62]

Lom J., Puytorac P. de 1965: Studies on the myxosporidian ultrastructure and polar capsule development. Protistologica 1: 53-65. [90]

Lom J., Corliss J.O. 1967: Ultrastructural observations on the development of the microsporidian protozoon Plistophora hyphessobryconis Schäperclaus. J. Protozool. 14: 141-152. [72]

Lom J., Corliss J.O., Noirot-Timothée C. 1968: Observations on the ultrastructure of the buccal apparatus in thigmotrich ciliates and their bearing on thigmotrich-peritrich affinities. J. Protozool. 15: 824-840. [40]

Lom J. 1969: Notes on the ultrastructure and sporoblast development in fish parasitizing myxosporidian of the genus Sphaeromyxa. Z. Zellforsch. 97: 416-437. [65]

Lom J. 1969: On a new taxonomic character in myxosporidia, as demonstrated in descriptions of two new species of Myxobolus. Folia Parasitol. 16: 97-103. [51]

Lom J., Laird M. 1969: Parasitic protozoa from marine and euryhaline fish of Newfoundland and New Brunswick. I. Peritrichous ciliates. Can. J. Zool. 47: 1367-1380. [44]
Lom J. 1970: Observations on trichodinid ciliates from freshwater fishes. Arch. Protistenkd. 112: 153-177. [36]

Lom J., Corliss J.O. 1970: Morphogenesis and cortical ultrastructure of Brooklynella hostilis, a dysteriid ciliate ectoparasitic on marine fishes. J. Protozool. 18: 261-281. [74]

Lom J., Hoffman G.L. 1971: Morphology of the spores of Myxosoma cerebralis (Hofer, 1903) and M. cartilaginis (Hoffman, Putz and Dunbar, 1965). J. Parasitol. 57: 13021308. [25] (Reprinted in J. Parasitol. 89: 653-657, 2003. "Defining the Field" article.)

Dyková I., Lom J. 1980: Tissue reaction to microsporidian infection in fish. J. Fish Dis. 3: 265-283. [42]

Levine N.D., Corliss J.O., Cox F.E.G., Deroux G., Grain J., Honigberg B.M., Leedale G.F., Loeblich A.R., Lom J., Lynn D., Merinfeld E.G., Page F.C., Polyansky G., Sprague V., Vávra J., Wallace F.G., Weiser J. 1980: A newly revised classification of the Protozoa. J. Protozool. 27: 3758. [483]

Dyková I., Lom J. 1981: Fish coccidia: critical notes on life cycles, classification and pathogenicity. J. Fish Dis. 4: 487-505. [79]

Canning E.U., Lom J., Nicholas J.P. 1982: Genus Glugea Thélohan, 1891 (Phylum Microspora): redescription of the type species Glugea anomala (Moniez, 1887) and recognition of its sporogonic development within sporophorous vesicles (pansporoblastic membranes). Protistologica 18: 193-210. [51]

Dyková I., Lom J. 1982: Sphaerospora renicola n. sp., a myxosporean from carp kidney and its pathogenicity. Z. Parasitenkd. 68: 259-268. [44]

Lom J., Dyková I., Pavlásková M. 1983: "Unidentified" mobile protozoans from the blood of carp and some unsolved problems of myxosporean life cycles. J. Protozool. 30: 497-508. [40]

Lom J., Noble E.R. 1984: Revised classification of the class Myxosporea Bütschli, 1881. Folia Parasitol. 31: 193-205. [77]

Lom J. 1987: Myxosporea: a new look at long-known parasites of fish. Parasitol. Today 3: 327-332. [50]

Lom J., Arthur J.R. 1989: A guideline for the preparation of species description in Myxosporea. J. Fish Dis. 12: 151156. [141]

Landsberg J.H., Lom J. 1991: Taxonomy of the genera of the Myxobolus/Myxosoma group (Myxobolidae, Myxosporea), current listing of species and revision of synonyms. Syst. Parasitol. 18: 165-186. [53]

Schlegel M., Lom J., Stechmann A., Bernard D., Leipe D., Dyková I., Sogin M.L. 1996: Phylogenetic analysis of complete small subunits ribosomal RNA coding region of Myxidium lieberkuehni: evidence that Myxozoa are Metazoa and related to Bilateria. Arch. Protistenkd. 147: 1-9. [61]

Lom J., McGeorge J., Feist S.W., Morris D., Adams A. 1997: Guidelines for the uniform characterisation of the actinosporean stages of parasites of the phylum Myxozoa. Dis. Aquat. Org. 30: 1-9. [53]

Lom J., Nilsen F. 2003: Fish microsporidia: fine structural diversity and phylogeny. Int. J. Parasitol. 33: 107-127. [21]

*[ ] - Times cited (ISI Web of Science ${ }^{\circledR}$ database). 